\title{
Long-term invasive follow-up of the everolimus-eluting bioresorbable vascular scaffold: five-year results of multiple invasive imaging modalities
}

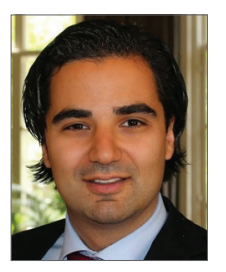

Cihan Simsek ${ }^{1}, \mathrm{MD}$; Antonios Karanasos ${ }^{1}, \mathrm{MD}$; Michael Magro', MD;

Hector M. Garcia-Garcia², MD, PhD; Yoshinobu Onuma², MD; Evelyn Regar ${ }^{1}, \mathrm{MD}, \mathrm{PhD}$;

Eric Boersma ${ }^{1}, \mathrm{PhD}$; Patrick W. Serruys ${ }^{1,2}, \mathrm{MD}, \mathrm{PhD}$; Robert J. van Geuns ${ }^{1 *}, \mathrm{MD}, \mathrm{PhD}$

1. Thoraxcenter, Erasmus Medical Center, Rotterdam, The Netherlands; 2. Cardialysis, Rotterdam, The Netherlands

GUEST EDITOR: Manel Sabaté, MD, PhD; Servicio de Cardiología, Clínic Hospital, Barcelona, Spain

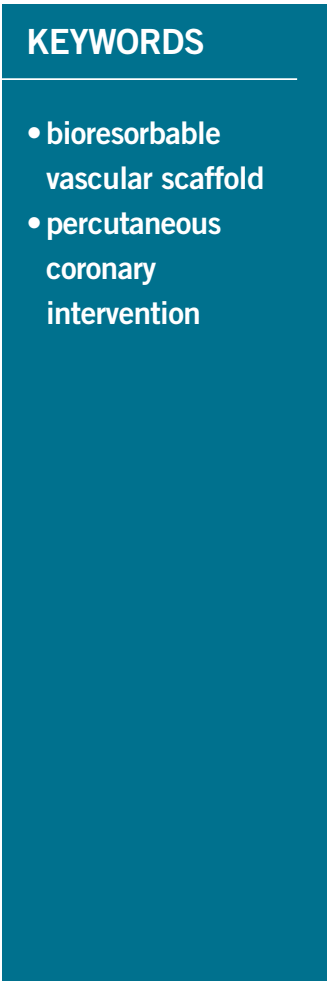

\begin{abstract}
Aims: Invasive imaging modalities have shown restoration of vasomotion, prevention of restenosis and, most importantly, increase in lumen area between six months and two years after first-generation everolimus-eluting bioresorbable vascular scaffold (Absorb BVS) implantation. Our aim was to assess whether these positive findings were sustained in the long term.

Methods and results: Patients included in the ABSORB cohort A from the Thoraxcenter Rotterdam cohort underwent coronary catheterisation including angiography, intravascular ultrasound (IVUS), virtual histology, optical coherence tomography (OCT) and vasomotion testing at five years. Eight out of 16 patients underwent catheterisation and scaffold assessment with multiple imaging modalities. A trend towards an increase in minimum luminal diameter was observed between two and five years by angiography $(1.95 \pm 0.37 \mathrm{~mm}$ vs. $2.14 \pm 0.38 \mathrm{~mm}$; $=0.09)$. IVUS data showed an increase in mean lumen area at five years $\left(6.96 \pm 1.13 \mathrm{~mm}^{2}\right)$ compared to six months $\left(6.17 \pm 0.74 \mathrm{~mm}^{2} ; \mathrm{p}=0.06\right)$ and two years $\left(6.56 \pm 1.16 \mathrm{~mm}^{2} ; \mathrm{p}=0.12\right)$, primarily due to a persistent reduction in plaque area size between six months and five years $\left(9.17 \pm 1.86 \mathrm{~mm}^{2}\right.$ vs. $7.57 \pm 1.63 \mathrm{~mm}^{2} ; \mathrm{p}=0.03$ ). The necrotic core area was reduced at five years compared to post-procedural results. In OCT, an increase in mean and minimal luminal area was observed. Moreover, no scaffold struts could be identified and a smooth endoluminal lining was observed. The scaffolded coronary segment did not show signs of endothelial dysfunction with acetylcholine testing.
\end{abstract}

Conclusions: At five years, the Absorb BVS is no longer discernible by any invasive imaging method and endothelial function is restored. Late luminal enlargement persists up to five years of follow-up without adaptive vessel remodelling.

\footnotetext{
*Corresponding author: Department of Cardiology, Thoraxcenter, Room Ba 585, Erasmus Medical Center, Dr. Molewaterplein 40,3015 RD Rotterdam, The Netherlands.E-mail: rvangeuns@erasmusmc.nl
} 


\section{Introduction}

Permanent metallic stents embedded in a coronary artery could preclude coronary revascularisation options, jail side branches, impair (long-term) endothelial function, impair non-invasive imaging and, most importantly, are associated with late and very late stent thrombosis ${ }^{1}$. Conceptually, a bioresorbable scaffold could help overcome these long-term pitfalls of metallic scaffolds.

The first-generation everolimus-eluting bioresorbable vascular scaffold (Absorb BVS; Abbott Vascular, Santa Clara, CA, USA) demonstrated safety and efficacy in 30 patients included in the BVS cohort A study ${ }^{1}$. At angiographic follow-up, the luminal late loss was $0.43 \pm 0.37 \mathrm{~mm}$ at six months and $0.48 \pm 0.28 \mathrm{~mm}$ at two years ${ }^{1,2}$. Intravascular ultrasound (IVUS) analysis revealed a decrease in scaffold area in the first six months together with low neointimal hyperplasia resulting in an overall reduction of $16.8 \%$ of the luminal area $^{3}$. Interestingly, both IVUS and optical coherence tomography (OCT) showed a luminal area enlargement between six months and two years due to a reduction in plaque size without change in vessel size ${ }^{2}$. One third of the scaffold struts could not be visualised by OCT at two years. Moreover, there was an optically homogeneous vessel wall structure suggesting healing of the coronary artery ${ }^{2}$.

Until now, the long-term scaffold biodegradation and vascular response following BVS implantation has not been systematically evaluated in human subjects. We aimed to assess the long-term vascular response of the first-generation everolimus-eluting BVS by multiple invasive imaging modalities, including IVUS, IVUS virtual histology (IVUS-VH), OCT and vasomotion testing.

\section{Methods \\ PATIENT POPULATION}

The design of the ABSORB cohort A study has already been published $^{1}$. For the present study, we included patients from the Thoraxcenter Rotterdam cohort of the ABSORB cohort A study $(n=16)$. All living patients $(n=14$; two patients died from a non-cardiac cause at 706 and 808 days post procedure, one from duodenal perforation and one from Hodgkin's disease) were asked to participate in this study. Eight out of 16 patients of the Rotterdam cohort of the ABSORB A trial provided written informed consent and underwent catheterisation and scaffold assessment with multiple imaging modalities between March 8 and July 20, 2012 (Figure 1).

The long-term single-centre follow-up imaging data (quantitative coronary angiography, vasomotion test, greyscale intravascular ultrasound, virtual histology) were analysed by an independent core laboratory (Cardialysis BV, Rotterdam, The Netherlands) and compared to previous core laboratory data-on-file from the ABSORB cohort A study. OCT image analysis was performed by an independent researcher in the Erasmus Medical Center (AK).

\section{STUDY PROCEDURES}

The definitions of individual parameters have already been described in a prior manuscript ${ }^{2}$. The clinical endpoints included cardiac death, myocardial infarction, stent thrombosis and ischaemiadriven target lesion revascularisation according to the definitions

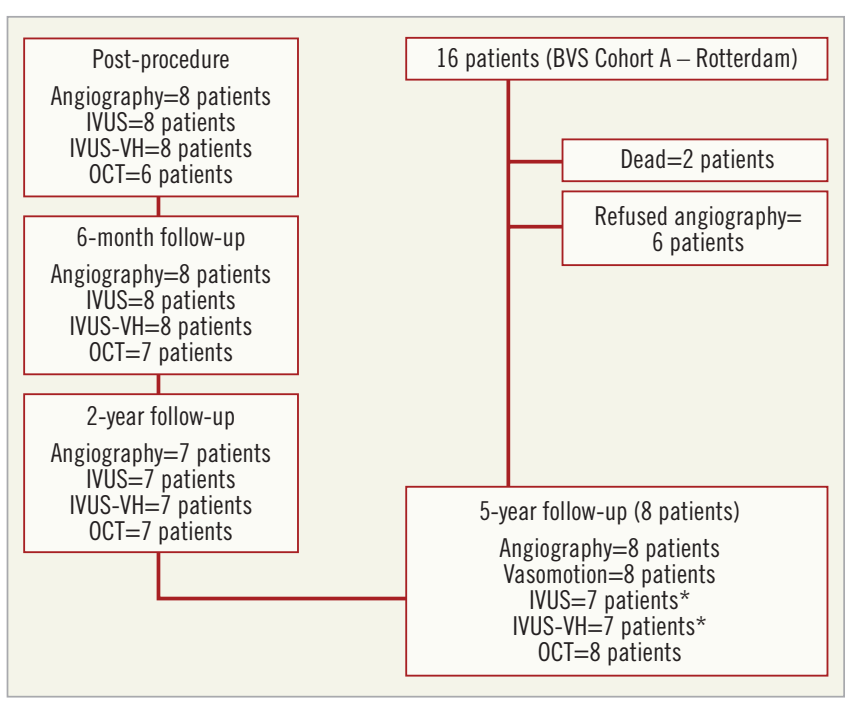

Figure 1. Flow chart showing the patients included in the five-year follow-up study. *IVUS data could not be acquired for one of the included patients at five-year follow-up.

from the Academic Research Consortium ${ }^{4}$. Endothelium-dependent and endothelium-independent coronary vasomotion were studied using standard protocols ${ }^{5}$. Endothelial dysfunction was defined as vasoconstriction of $>3 \%$ in mean vessel diameter between baseline and maximum dose acetylcholine (Ach).

IVUS acquisitions were performed using an Eagle Eye $^{\circledR}$ catheter (Volcano Corp., Rancho Cordova, CA, USA) with automated continuous pullback at $0.5 \mathrm{~mm} / \mathrm{sec}$. IVUS-VH utilises backscattering of radiofrequency signals to provide information about tissue composition of the vessel wall. Four different plaque compositions, i.e., fibro-fatty, fibrous tissue, dense calcium and necrotic core were assessed on each cross-section and expressed as percentage (with each area totalling 100\%). The polymeric scaffold struts were detected as dense calcified areas surrounded by necrotic core due to the strong backscattering properties of the polymer. The changes of these areas between implantation and follow-up were used as a surrogate marker to assess the polymer bioabsorption process. The methodology of OCT image acquisition for the baseline, six-month and two-year follow-up, using a first-generation OCT system with occlusive technique, has been previously described ${ }^{1,2}$. At five-year follow-up, all eight subjects underwent second-generation, nonocclusive OCT imaging using the commercially available C7 XR imaging console and the Dragonfly ${ }^{\mathrm{TM}}$ intravascular imaging catheter (both St. Jude Medical, St. Paul, MN, USA). Image acquisition has been previously described ${ }^{6}$.

Scaffolds were assessed for the presence of incomplete apposition, intra-scaffold dissection and irregular lumen shape. Incomplete strut apposition was defined as the complete separation between strut and vessel wall with a distance larger than the strut thickness. Scaffolds with at least one incompletely apposed strut were considered incompletely apposed. Incompletely apposed struts located in front of side branch ostia, were considered side branch-related 
struts and analysed separately. The number of side branches per scaffold with side branch-related incomplete strut apposition was recorded. Irregular lumen shape was defined as the presence of multiple intimal protrusions. Plaque morphology in each frame at five years was characterised, according to definitions used for native atherosclerosis, as fibrous, fibrocalcific and fibroatheromatous ${ }^{6}$. In the case of fibroatheromas, fibrous cap thickness was assessed and fibroatheromas with cap thickness $<65 \mu \mathrm{m}$ were classified as thincap fibroatheromas ${ }^{7}$.

\section{STATISTICAL ANALYSIS}

This study was designed to provide preliminary observations and generate hypotheses for future studies. Baseline and procedural variables are presented as mean ( \pm standard deviation [SD]) for continuous variables and as percentages for categorical variables. Paired comparisons of measurements performed after the procedure and in the different follow-up intervals were done by a Wilcoxon's signed rank test. No statistical adjustment was applied on the data set since no formal hypothesis testing was planned. The $p$-values represent exploratory analysis only and should therefore be interpreted with caution. All reported p-values are two-sided and regarded as statistically significant if $\leq 0.05$. Statistical analysis was performed with SPSS for Windows version 15 (SPSS Inc., Chicago, IL, USA).

\section{Results}

The baseline characteristics of the population are shown in Table 1. At five years, there were no cardiac deaths, stent thromboses or myocardial infarctions, and only one patient had a target vessel revascularisation (TVR) at 106 days and 1,780 days and a target lesion revascularisation (TLR) at 2,218 days. At 106 days, the patient underwent catheterisation due to persistent chest pain. The Absorb BVS in the distal circumflex coronary artery was patent; however, the proximal circumflex coronary artery showed a narrowing with occlusive spasm on further testing with methergine. A paclitaxel-eluting stent was placed in the proximal circumflex coronary which was $7 \mathrm{~mm}$ from the proximal edge of the Absorb BVS. At 1,780 days, the patient had a repeat angiography for recurrence of stable angina. This time an everolimus-eluting stent was used to treat a significant de novo lesion in the intermediate branch. At 2,218 days, the angiographic follow-up performed because of this study showed a significant lesion distal of the Absorb
Table 1. Baseline and procedural characteristics. Number of patients $(n=8)$ BVS

\begin{tabular}{|c|c|c|}
\hline \multirow{2}{*}{$\begin{array}{l}\text { Demographic } \\
\text { characteristics }\end{array}$} & Age, years $( \pm S D)$ & $65.1( \pm 8.6)$ \\
\hline & Male, \% & $75(6 / 8)$ \\
\hline \multirow{2}{*}{$\begin{array}{l}\text { Cardiac history } \\
\text { (\%) }\end{array}$} & Prior target vessel intervention & $12.5(1 / 8)$ \\
\hline & Prior myocardial infarction & $12.5(1 / 8)$ \\
\hline \multirow[t]{4}{*}{ Risk factors (\%) } & Current smoking & $12.5(1 / 8)$ \\
\hline & Hypertension & $50(4 / 8)$ \\
\hline & Hypercholesterolaemia & $37.5(3 / 8)$ \\
\hline & Diabetes & $12.5(1 / 8)$ \\
\hline \multirow[t]{3}{*}{ Treated vessel (\%) } & RCA & $12.5(1 / 8)$ \\
\hline & LAD & $37.5(3 / 8)$ \\
\hline & LCX & $50.0(4 / 8)$ \\
\hline \multirow{4}{*}{$\begin{array}{l}\text { ACC lesion type } \\
(\%)\end{array}$} & A & $0(0 / 8)$ \\
\hline & B1 & $50(4 / 8)$ \\
\hline & B2 & $50(4 / 8)$ \\
\hline & C & $0(0 / 8)$ \\
\hline \multirow[t]{4}{*}{ QCA } & Mean reference vessel diameter, $\mathrm{mm}( \pm \mathrm{SD})$ & $3.0( \pm 0.6)$ \\
\hline & Minimum luminal diameter, $\mathrm{mm}( \pm S \mathrm{SD})$ & $1.1( \pm 0.3)$ \\
\hline & Diameter stenosis, \% ( \pm SD) & $64.6( \pm 10.7)$ \\
\hline & Lesion length, mm ( \pm SD) & $10.8( \pm 4.0)$ \\
\hline
\end{tabular}

Data are presented as percentages or means $( \pm S D)$. SD: standard deviation; RCA: right coronary artery; LAD: left anterior descending coronary artery; LCX: left circumflex coronary artery.

BVS scaffold with a fractional flow reserve of 0.79 . This lesion was located within $5 \mathrm{~mm}$ of the distal marker of the Absorb BVS and treated with a Tryton bifurcation stent (Tryton Medical, Inc., Durham, NC, USA) and an everolimus-eluting stent.

At five-year angiography, there was no evidence of significant stenosis in the coronary artery segments scaffolded by the Absorb BVS as identified by the proximal and distal radiopaque markers. All patients showed an increase in minimum luminal diameter (MLD) compared to the previous invasive follow-up at two years (except for one patient who did not have angiographic follow-up at two years). The patient-level data regarding MLD are depicted in Table 2. Overall, there was a trend towards an increase in MLD at five years $(2.14 \pm 0.38 \mathrm{~mm})$ compared to two years $(1.95 \pm 0.37 \mathrm{~mm}$; $\mathrm{p}=0.09)$, resulting in a decrease in late loss $(0.22 \pm 0.34 \mathrm{~mm}$ vs. $0.39 \pm 0.31 \mathrm{~mm} ; \mathrm{p}=0.09$; respectively).

Table 2. Quantitative coronary angiography.

\begin{tabular}{|c|c|c|c|c|c|c|c|c|}
\hline $\begin{array}{l}\text { Quantitative coronary } \\
\text { angiography }\end{array}$ & $\begin{array}{c}\text { Before } \\
\text { procedure }\end{array}$ & $\begin{array}{c}\text { After } \\
\text { procedure }\end{array}$ & 6 months & 2 years & 5 years & $\begin{array}{l}\boldsymbol{p} \text {-value after } \\
\text { procedure } \\
\text { vs. } 5 \text { years }\end{array}$ & $\begin{array}{c}p \text {-value } \\
6 \text { months } \\
\text { vs. } 5 \text { years }\end{array}$ & $\begin{array}{c}p \text {-value } \\
2 \text { years } \\
\text { vs. } 5 \text { years }\end{array}$ \\
\hline N & 8 & 8 & 8 & 7 & 8 & & & \\
\hline Reference vessel diameter (mm) & $3.02( \pm 0.56)$ & $3.04( \pm 0.20)$ & $2.93( \pm 0.21)$ & $2.78( \pm 0.08)$ & $2.83( \pm 0.30)$ & 0.02 & 0.67 & 0.74 \\
\hline $\begin{array}{l}\text { In-scaffold minimum luminal } \\
\text { diameter }(\mathrm{mm})\end{array}$ & $1.06( \pm 0.30)$ & $2.36( \pm 0.30)$ & $2.10( \pm 0.31)$ & $1.95( \pm 0.37)$ & $2.14( \pm 0.38)$ & 0.09 & 0.67 & 0.09 \\
\hline In-scaffold diameter stenosis (\%) & $64.56( \pm 10.66)$ & $22.33( \pm 6.68)$ & $28.19( \pm 10.99)$ & $29.93( \pm 13.26)$ & $24.67( \pm 9.77)$ & 0.21 & 0.50 & 0.07 \\
\hline In-scaffold late loss (mm) & - & - & $0.26( \pm 0.25)$ & $0.39( \pm 0.31)$ & $0.22( \pm 0.34)$ & - & 0.67 & 0.09 \\
\hline
\end{tabular}


In keeping with the angiographic findings, IVUS data showed a trend towards an increase in mean lumen area at five years $\left(6.96 \pm 1.13 \mathrm{~mm}^{2}\right)$ compared to six months $\left(6.17 \pm 0.74 \mathrm{~mm}^{2} ; \mathrm{p}=0.06\right)$ and two years $\left(6.56 \pm 1.16 \mathrm{~mm}^{2} ; \mathrm{p}=0.12\right)$ (Table 3$)$. This was primarily due to a persistent reduction in plaque size between six months and five years $\left(9.17 \pm 1.86 \mathrm{~mm}^{2}\right.$ vs. $\left.7.57 \pm 1.63 \mathrm{~mm}^{2} ; \mathrm{p}=0.03\right)$, resulting in an increased lumen area with no evidence of vessel dilatation/ectasia. Dense calcium area and necrotic core area were significantly reduced at five years when compared to baseline (Table 3). The dense calcium area significantly decreased from $1.32 \pm 0.75 \mathrm{~mm}^{2}$ to $0.52 \pm 0.51 \mathrm{~mm}^{2}$ ( $\mathrm{p}=0.03$ ), whereas the necrotic core area decreased from $1.79 \pm 0.80 \mathrm{~mm}^{2}$ to $0.74 \pm 0.66 \mathrm{~mm}^{2}(\mathrm{p}=0.03)$. The greatest reduction in these components occurred within two years after Absorb BVS implantation. No changes in plaque composition were observed between two and five years.

At five-year follow-up, mean and minimum luminal area by OCT were significantly increased compared to the six-month and the twoyear follow-up, while there was no significant difference from baseline measurements immediately after the index procedure (Figure 2, Table 4). No scaffold struts could be identified by OCT at five years, providing evidence of a continued and completed resorption process from the second year on. Morphological assessment is represented in Table 4. Multiple luminal protrusions which caused a corrugated ring appearance in all patients at six months were no longer evident in any patient by five years. All baseline intra-scaffold dissections $(n=5)$ were healed by five years. Two patients showed a focally irregular lumen contour, one of whom had a short intimal dissection, not present at earlier investigations, at the overlap between the BVS and a metallic stent implanted at baseline as a bail-out procedure. There was no incomplete scaffold apposition in any case, as scaffold struts could not be detected. Side branch-related incomplete scaffold apposition was identified in seven out of eight scaffolds at previous

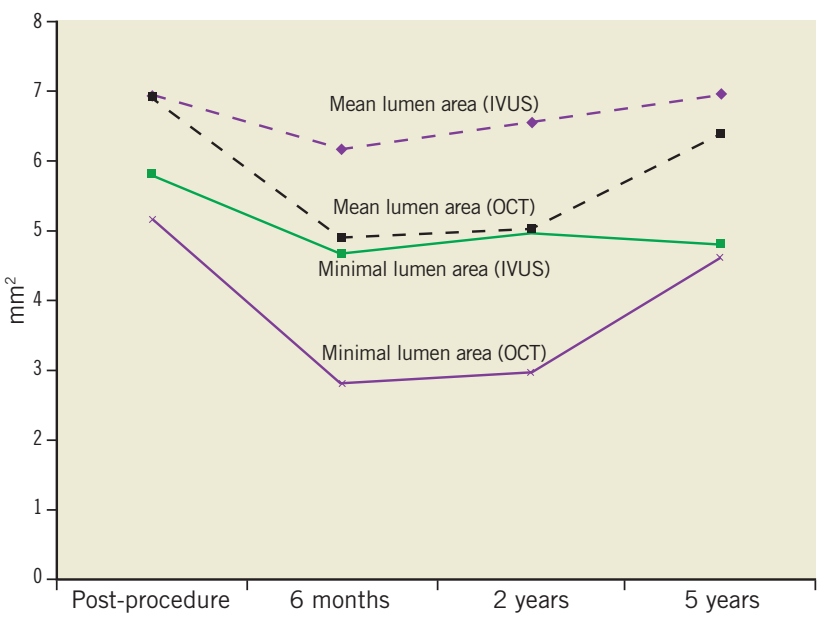

Figure 2. Mean and minimum luminal area of IVUS and OCT analysis.

follow-ups, while, at the five-year follow-up of the same patients, tissue bridges/neocarina (Figure 3) were evident at the site of previously detected side branch-related struts.

Endothelium-dependent vasomotion was present in the proximal and distal scaffold coronary segment as the mean lumen diameter decreased by $3.2 \%$ (from $2.53 \mathrm{~mm}$ to $2.45 \mathrm{~mm}$ ) and $5.2 \%$ (from $2.49 \mathrm{~mm}$ to $2.36 \mathrm{~mm}$ ), respectively, after maximum dose Ach compared to baseline angiography. Endothelium-independent vasomotion was not observed in the proximal or distal segment. Neither endothelium-dependent nor endothelium-independent vasomotion was observed in the scaffolded coronary segment, due to a heterogeneous response of four patients showing vasoconstriction and four patients showing vasodilatation on maximum dose Ach. A detailed individual response is depicted in Figure 4.

Table 3. Intravascular ultrasound and intravascular ultrasound virtual histology.

\begin{tabular}{|c|c|c|c|c|c|c|c|}
\hline & $\begin{array}{c}\text { After } \\
\text { procedure }\end{array}$ & 6 months & 2 years & 5 years & $\begin{array}{l}p \text {-value after } \\
\text { procedure } \\
\text { vs. } 5 \text { years }\end{array}$ & $\begin{array}{c}\text { p-value } \\
6 \text { months } \\
\text { vs. } 5 \text { years }\end{array}$ & $\begin{array}{c}\text { p-value } \\
2 \text { years } \\
\text { vs. } 5 \text { years }\end{array}$ \\
\hline N & 8 & 8 & 7 & 7 & & & \\
\hline \multicolumn{8}{|l|}{ Greyscale IVUS } \\
\hline Vessel area $\left(\mathrm{mm}^{2}\right)$ & $15.72( \pm 3.00)$ & $15.34( \pm 2.00)$ & $14.09( \pm 1.66)$ & $14.52( \pm 1.81)$ & 0.60 & 0.40 & 0.75 \\
\hline Average lumen area $\left(\mathrm{mm}^{2}\right)$ & $6.95( \pm 0.63)$ & $6.17( \pm 0.74)$ & $6.56( \pm 1.16)$ & $6.96( \pm 1.13)$ & 0.75 & 0.06 & 0.12 \\
\hline Plaque area $\left(\mathrm{mm}^{2}\right)$ & $8.78( \pm 2.83)$ & $9.17( \pm 1.86)$ & $7.54( \pm 1.24)$ & $7.57( \pm 1.63)$ & 0.60 & 0.03 & 0.92 \\
\hline Minimum lumen area $\left(\mathrm{mm}^{2}\right)$ & $5.81( \pm 0.62)$ & $4.67( \pm 0.77)$ & $4.96( \pm 1.08)$ & $4.81( \pm 2.04)$ & 0.60 & 0.74 & 0.75 \\
\hline \multicolumn{8}{|l|}{ IVUS-VH } \\
\hline Dense calcium (\%) & $23.31( \pm 8.40)$ & $18.85( \pm 7.59)$ & $15.43( \pm 6.89)$ & $14.40( \pm 6.18)$ & 0.03 & 0.40 & 0.46 \\
\hline Dense calcium area $\left(\mathrm{mm}^{2}\right)$ & $1.32( \pm 0.75)$ & $1.01( \pm 0.40)$ & $0.55( \pm 0.31)$ & $0.52( \pm 0.51)$ & 0.03 & 0.09 & 0.12 \\
\hline Fibro-fatty (\%) & $5.31( \pm 3.28)$ & $6.33( \pm 4.15)$ & $8.05( \pm 5.86)$ & $10.43( \pm 3.19)$ & 0.03 & 0.13 & 0.25 \\
\hline Fibro-fatty area $\left(\mathrm{mm}^{2}\right)$ & $0.34( \pm 0.28)$ & $0.36( \pm 0.30)$ & $0.28( \pm 0.25)$ & $0.35( \pm 0.23)$ & 0.92 & 0.31 & 0.75 \\
\hline Fibrous (\%) & $41.00( \pm 8.50)$ & $51.50( \pm 8.85)$ & $51.06( \pm 9.00)$ & $55.31( \pm 9.55)$ & 0.03 & 0.50 & 0.25 \\
\hline Fibrous area $\left(\mathrm{mm}^{2}\right)$ & $2.48( \pm 1.22)$ & $2.94( \pm 1.31)$ & $1.77( \pm 0.47)$ & $1.85( \pm 1.05)$ & 0.60 & 0.06 & 0.92 \\
\hline Necrotic core (\%) & $30.38( \pm 4.71)$ & $23.32( \pm 8.23)$ & $25.46( \pm 9.37)$ & $19.86( \pm 6.62)$ & 0.03 & 0.40 & 0.17 \\
\hline Necrotic core area $\left(\mathrm{mm}^{2}\right)$ & $1.79( \pm 0.80)$ & $1.29( \pm 0.74)$ & $0.90( \pm 0.43)$ & $0.74( \pm 0.66)$ & 0.03 & 0.18 & 0.03 \\
\hline
\end{tabular}


Table 4. Quantitative and qualitative OCT findings.

\begin{tabular}{|c|c|c|c|c|c|c|c|c|c|c|c|c|c|c|c|}
\hline \multicolumn{2}{|c|}{ Table measurements } & \multicolumn{3}{|c|}{ After procedure } & \multicolumn{2}{|c|}{6 months } & \multicolumn{2}{|c|}{2 years } & \multicolumn{2}{|c|}{5 years } & \multicolumn{2}{|c|}{$\begin{array}{c}p \text {-value after } \\
\text { procedure } \\
\text { vs. } 5 \text { years }\end{array}$} & \multicolumn{2}{|c|}{$\begin{array}{c}p \text {-value } \\
6 \text { months } \\
\text { vs. } 5 \text { years }\end{array}$} & $\begin{array}{c}p \text {-value } \\
2 \text { years } \\
\text { vs. } 5 \text { years }\end{array}$ \\
\hline \multicolumn{2}{|l|}{ N } & \multicolumn{3}{|c|}{6} & \multicolumn{2}{|l|}{7} & \multicolumn{2}{|c|}{7} & \multicolumn{2}{|c|}{8} & & & & & \\
\hline \multicolumn{2}{|c|}{ Minimal lumen area, $\mathrm{mm}^{2}$} & \multicolumn{3}{|c|}{$5.16 \pm 0.74$} & \multicolumn{2}{|c|}{$2.81 \pm 1.57$} & \multicolumn{2}{|c|}{$2.97 \pm 1.26$} & \multicolumn{2}{|c|}{$4.62 \pm 1.44$} & \multicolumn{2}{|r|}{0.60} & \multicolumn{2}{|r|}{0.02} & 0.02 \\
\hline \multicolumn{2}{|c|}{ Mean lumen area, mm² } & \multicolumn{3}{|c|}{$6.91 \pm 0.88$} & \multicolumn{2}{|c|}{$4.89 \pm 1.29$} & \multicolumn{2}{|c|}{$5.03 \pm 1.24$} & \multicolumn{2}{|c|}{$6.39 \pm 1.18$} & \multicolumn{2}{|r|}{0.46} & \multicolumn{2}{|r|}{0.03} & 0.02 \\
\hline $\begin{array}{c}\text { Table patient } \\
\text { level }\end{array}$ & \multicolumn{3}{|c|}{$\begin{array}{l}\text { Incomplete scaffold } \\
\text { apposition }\end{array}$} & \multicolumn{4}{|c|}{$\begin{array}{l}\text { Side branches with side branch } \\
\text { struts or tissue bridges (n) }\end{array}$} & \multicolumn{4}{|c|}{$\begin{array}{l}\text { Intra-scaffold } \\
\text { dissection }\end{array}$} & \multicolumn{3}{|c|}{$\begin{array}{l}\text { Irregular } \\
\text { Iumen shape }\end{array}$} & $\begin{array}{c}\text { Plaque } \\
\text { characterisation* }\end{array}$ \\
\hline $\begin{array}{l}\text { Months since } \\
\text { implantation }\end{array}$ & 0 & 6 & 24 & 0 & 6 & 24 & 60 & 0 & 6 & 24 & 60 & 6 & 24 & 60 & 60 \\
\hline Patient 1 & - & - & - & 1 & 1 & 1 & 1 & + & - & - & - & + & - & - & Fibroatheroma/fibrous \\
\hline Patient 2 & $N / A$ & - & - & $N / A$ & 3 & 3 & 3 & $N / A$ & + & - & - & + & - & - & $\begin{array}{l}\text { Fibrous/fibroatheroma/ } \\
\text { fibrocalcific }\end{array}$ \\
\hline Patient 3 & - & - & - & 2 & 2 & 2 & 1 & + & - & - & - & + & - & - & Fibrous/fibroatheroma \\
\hline Patient 4 & + & + & - & 1 & 1 & 1 & 1 & - & - & - & - & + & - & - & $\begin{array}{l}\text { Thin-cap fibroatheroma/ } \\
\text { fibrous }\end{array}$ \\
\hline Patient 5 & - & - & N/A & 2 & 2 & $\mathrm{~N} / \mathrm{A}$ & 2 & - & - & $\mathrm{N} / \mathrm{A}$ & - & + & $\mathrm{N} / \mathrm{A}$ & - & Fibrocalcific/fibroatheroma \\
\hline Patient 6 & - & - & - & 2 & 2 & 2 & 2 & + & + & - & - & + & + & - & Fibrous/fibroatheroma \\
\hline Patient 7 & - & - & - & 0 & 0 & 0 & 0 & + & + & - & - & + & + & - & Fibrous \\
\hline Patient 8 & $\mathrm{~N} / \mathrm{A}$ & N/A & - & $\mathrm{N} / \mathrm{A}$ & $\mathrm{N} / \mathrm{A}$ & 3 & 3 & $\mathrm{~N} / \mathrm{A}$ & $\mathrm{N} / \mathrm{A}$ & - & - & $\mathrm{N} / \mathrm{A}$ & - & - & $\begin{array}{l}\text { Fibrous/fibrocalcific/ } \\
\text { fibroatheroma }\end{array}$ \\
\hline
\end{tabular}

Data are presented as $\mathrm{mm}^{2}( \pm \mathrm{SD})$. The table consists of quantitative (top) and individual qualitative OCT findings (beneath) at different follow-up intervals. + positive; -: negative; N/A: not available

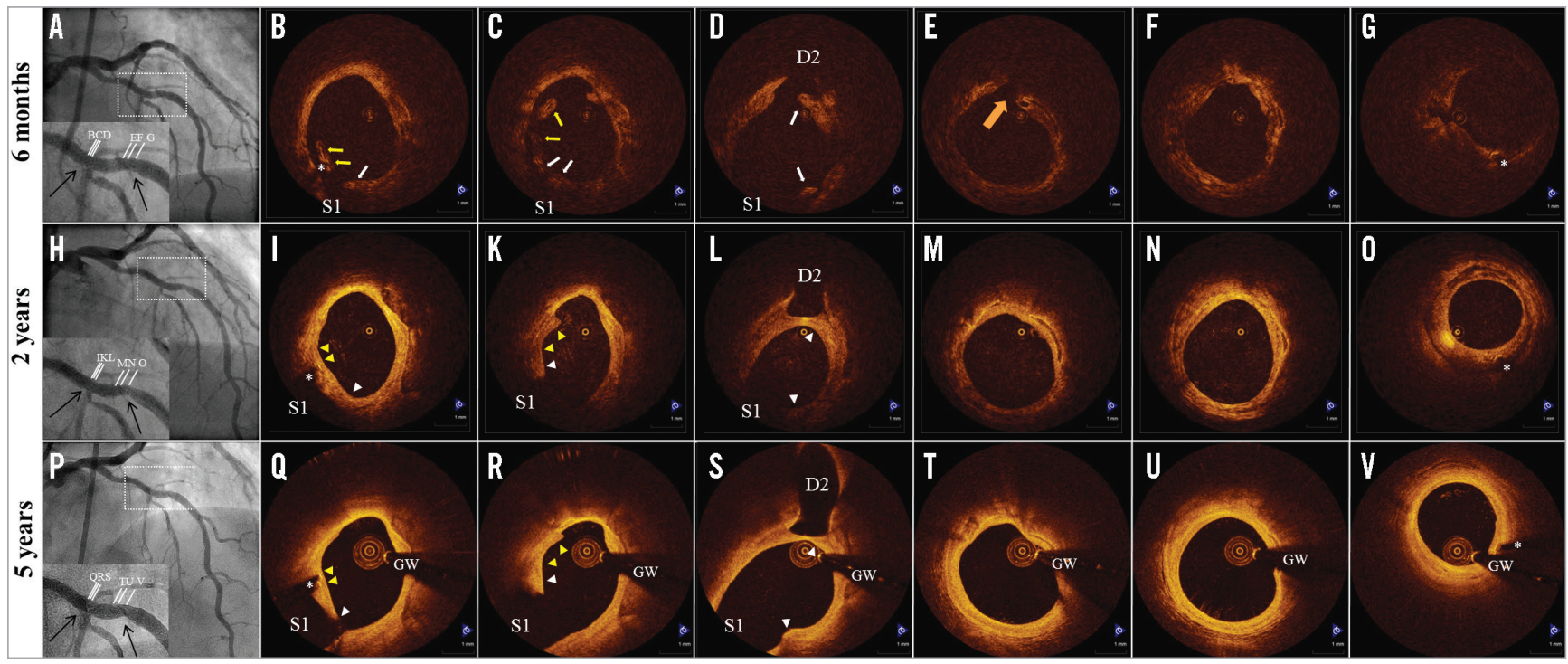

Figure 3. Serial assessment of scaffold-vascular wall interaction by optical coherence tomography (OCT) in patient 2. A) Coronary angiography six months after BVS implantation at the mid left anterior descending artery. Arrows indicate position of the radiopaque markers at the extremities of the scaffold. B-G) OCT assessment six months after BVS implantation. Incompletely apposed struts (yellow arrows) and side branch-related struts (white arrows) in front of diagonal and septal branches were visualised. Intra-scaffold dissection (orange arrow) and irregular lumen shape can be identified in panels $E$ and F, respectively. H) Coronary angiography 24 months after BVS implantation. I-O) OCT assessment 24 months after BVS implantation. Previously incompletely apposed struts (yellow arrowheads) were integrated into the vessel wall (panels I-K), while side branch-related struts (white arrowheads) were connected by neointimal tissue bridges (panels I-L). Healing of the intra-scaffold dissection and recovery of regular lumen shape. P) Coronary angiography 74 months after BVS implantation. Q-V) OCT assessment 74 months after BVS implantation. Complete disappearance of the struts from the vascular wall and replacement by a signal-rich intimal layer that is separating the underlying plaque (fibrocalcific plaque-fibroatheroma) from the lumen. Note also the complete biodegradation of side branch-related struts and the thinning of tissue bridges. Asterisks indicate stent markers, GW indicates guidewire artefact, S1 indicates ostium of the septal branch and D2 of the diagonal branch. 


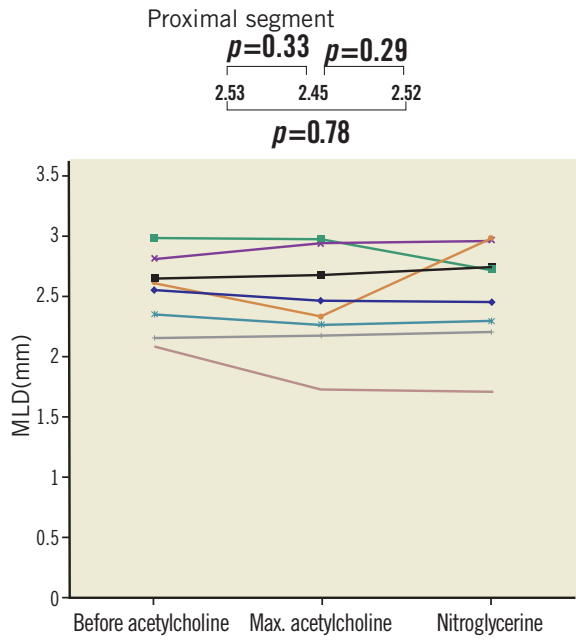

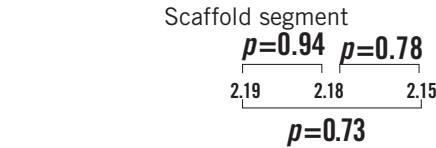

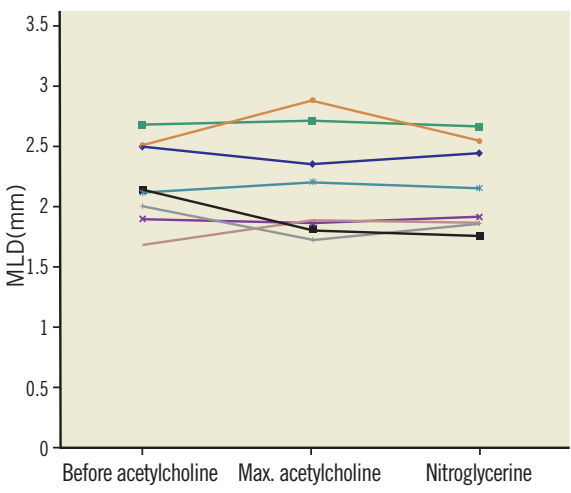

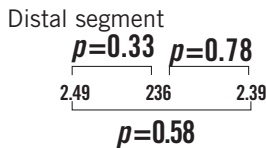

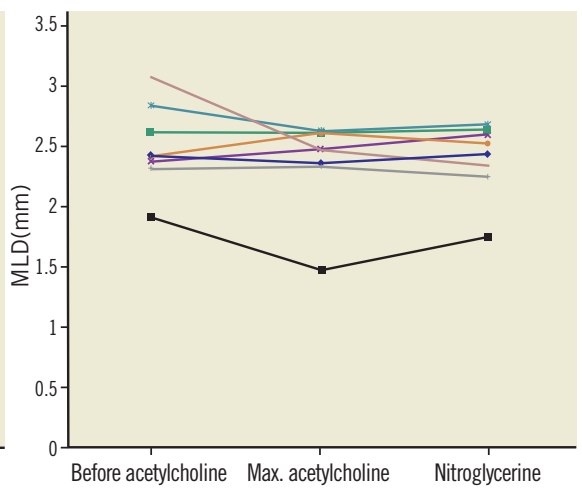

Figure 4. Vasomotion testing. In these graphs you can see the individual changes of the patients in the proximal coronary segment, scaffold segment and distal segment. At the top, the MLD with the p-values are presented.

\section{Discussion}

The main findings of the current study are the following. 1) The bioresorption process of the Absorb BVS has been completed, as no scaffold struts could be identified by OCT and dense calcium area and necrotic core area by IVUS-VH were significantly reduced at five years compared to baseline. 2) As suggested by OCT analysis, there is no evidence of incompletely apposed struts or struts jailing side branch ostia, and all baseline dissections were healed. 3 ) There was a trend towards an increase in mean and minimum lumen area at five years compared to two years as assessed by angiography and IVUS, while a significant increase was observed by OCT. The increase was primarily due to a persistent reduction in plaque area up to five years with no evidence of a change in vessel size. 4) The scaffolded coronary segments did not show signs of endothelial dysfunction, whereas a heterogeneous response of the scaffolded coronary segments was observed in response to vasoactive agents. Overall, neither endothelium-dependent nor endothelium-independent vasomotion could be observed in the scaffolded coronary segment.

In the current study, four different intravascular imaging modalities demonstrated consistently that the bioresorption process of the first-generation Absorb BVS has been fully completed. There is a remarkable persistent late luminal enlargement and a reduction in plaque area without outward vessel remodelling up to five years after the first-generation Absorb BVS implantation. Recently, positive long-term findings were also reported for the non-drugeluting fully biodegradable self-expanding Igaki-Tamai stent (Kyoto Medical Planning Co., Ltd., Kyoto, Japan; formerly, Igaki Medical Planning Co., Ltd. $)^{8}$. In a limited cohort of 50 patients, the struts mostly disappeared within three years after implantation as assessed by IVUS data, although no other imaging modalities with higher sensitivity for detecting scaffold struts were utilised. In that study, the overall major adverse cardiac events rate was acceptable with a target lesion revascularisation rate of $28 \%$ at 10 years ${ }^{8}$.
In our small cohort, there were no target lesion revascularisations performed in patients treated with the first-generation Absorb BVS at five-year follow-up (only one patient had a TLR at 2,218 days). This beneficial efficacy outcome of the Absorb BVS could have been caused by differences in scaffold design (such as balloonexpanding, drug-eluting, thinner strut thickness and less maximum circular unsupported scaffold area), but also due to intrinsic differences between the two scaffolds. Knowledge of the specific timeline and completion of the bioresorption process of the Absorb BVS in human coronary arteries is very important, as the scaffold should ideally provide uniform radial support for a certain period and afterwards preferably be fully bioresorbed to restore natural physiologic vasomotor function. The Absorb BVS characteristics come closer to achieving this ideal equilibrium, which may have contributed to this favourable efficacy outcome of our patient population.

Our previous published reports with a multi-imaging approach have shown that the bioresorption process of the Absorb BVS was still ongoing at two-year follow-up, as two thirds of the struts were still visible by $\mathrm{OCT}^{2}$. Our group recently reported that only one sixth of the struts were recognisable at four years by OCT in a porcine model $^{9}$. In the current study, none of the struts was discernible by OCT at five years, suggesting a faster resorption process in human coronary arteries compared to porcine coronary arteries. Analysis of virtual histology data corroborates this finding, as the dense calcium area and necrotic core area, which can be used as a surrogate marker of the bioresorption process of polymeric struts, were significantly reduced at five years compared to baseline.

IVUS data showed a tendency towards an increase in mean lumen area at five years compared to six months and two years, primarily due to a persistent reduction in plaque area up to five years. A relative reduction in plaque area of $14 \%$ in five years achieved by this local treatment has not been observed before. Therefore, it could 
even have better plaque-reducing capabilities than (high-intensity) statin treatment, which showed only a reduction of roughly $1 \%$ in percentage atheroma volume at two years ${ }^{10}$. Although all patients were on statin treatment, this observed major decrease in plaque area size is an interesting finding that needs further research.

The OCT findings are consistent with a favourable healing response and the absence of device-induced vascular wall toxicity. This is of importance as first-generation drug-eluting stents have been associated with an impaired healing response and vascular toxicity, factors contributing to very late stent thrombosis ${ }^{11}$. Furthermore, metallic platforms have been associated with the development of neoatherosclerosis, which can also contribute to very late stent thrombosis, reported to occur even 15 years following stent implantation ${ }^{12}$. In our patients, OCT revealed the complete disappearance of scaffold struts. We assume, based on the vast evidence in the literature, that this vascular reaction is favourable and potentially reduces the risk of very late stent thrombosis. We further speculate that the observed development of a homogeneous tissue layer over the underlying plaque together with the possibility of observed everolimus-induced autophagy of the macrophages could reduce the risk of new thrombotic events caused by plaque progression ${ }^{13}$.

The previous two-year report observed the presence of a functionally active endothelium at the site of the scaffold implantation ${ }^{2}$. In fact, five out of nine patients tested showed vasodilatation with intracoronary acetylcholine. In the present study, four out of eight patients had a more than $3 \%$ increase in vessel size after maximum dose of acetylcholine. Two other patients had a less than $3 \%$ response, while two patients had more than $3 \%$ vasoconstriction $(3.9 \%)$. These findings are consistent with restoration and preservation of vasomotor function in the scaffolded segment, a desirable effect observed in the absence of a rigid structure.

This study provides evidence for the first time that the beneficial effects of the bioresorbable scaffold are sustained five years after implantation, and of an ongoing lumen enlargement from two years to five years with concomitant reduction in plaque area. Further clinical evidence from ongoing BVS studies can corroborate the current hypothesis and provide a role for BVS in the treatment of coronary artery disease. Furthermore, in the light of the findings of the PROSPECT study, which concluded that specific morphological characteristics of non-culprit lesions in patients with acute coronary syndrome are associated with future events, a device with a favourable safety profile that can shield the lumen from the underlying plaque by a protective homogeneous layer without causing any luminal compromise in the long term could conceptually be used in the setting of high-risk non-stenotic lesions in the future ${ }^{14}$.

\section{Limitations}

The current study had some limitations. It included a small number of patients and therefore the various parameters that were investigated should be considered as exploratory. Moreover, not all patients who were invited participated in this study. Whether our findings are representative of the whole cohort remains questionable. However, baseline clinical and angiographic characteristics were not different from the entire ABSORB cohort A which can be expected to behave similarly. Third, OCT was performed using a second-generation system with a non-occlusive technique, whereas previous OCT examinations were performed with a first-generation system with proximal balloon occlusion. Although second-generation OCT is associated with a better imaging quality and high reproducibility, it might have slightly overestimated luminal measurements.

\section{Conclusions}

In conclusion, the observations made in the current study suggest a highly beneficial clinical and invasive imaging outcome at longterm follow-up. In this series of patients, there was evidence of small but consistent late lumen enlargement at five years, primarily caused by a reduction of the plaque area. The complete bioresorption of the scaffold without signs of endothelial dysfunction suggests the recovery of a functional vascular wall and the elimination of a substrate for late stent complications. All these beneficial findings need to be confirmed in larger studies.

\section{Impact on daily practice}

This is the first study describing the five-year results of several imaging modalities of patients treated with first-generation bioabsorbable vascular scaffolds. The results indicate that the bioabsorption process has been fully completed with a late luminal enlargement up to five years of follow-up without signs of adaptive vessel remodelling. The increase in luminal enlargement is due to an impressive reduction in plaque area of $14 \%$ in five years, which has not been observed before. These encouraging long-term results of the first-generation bioabsorbable vascular scaffolds will pave the way for larger randomised controlled trials in the future.

\section{Guest Editor}

This paper was Guest Edited by Manel Sabaté, MD, PhD, Servicio de Cardiología, Clínic Hospital, Barcelona, Spain.

\section{Funding}

The cost for this late follow-up study was fully covered by the Erasmus Medical Center. The institute has received research grants from Abbott Vascular for other projects.

\section{Conflict of interest statement}

R.J. van Geuns has received a speaker's fee and served on the European advisory board of Abbott Vascular. Y. Onuma has received a speaker's fee from Abbott Vascular. The other authors have no conflicts of interest to declare. The Guest Editor has no conflicts of interest to declare.

\section{References}

1. Ormiston JA, Serruys PW, Regar E, Dudek D, Thuesen L, Webster MW, Onuma Y, Garcia-Garcia HM, McGreevy R, Veldhof S. A bioabsorbable everolimus-eluting coronary stent system for 
patients with single de-novo coronary artery lesions (ABSORB): a prospective open-label trial. Lancet. 2008;371:899-907.

2. Serruys PW, Ormiston JA, Onuma Y, Regar E, Gonzalo N, Garcia-Garcia HM, Nieman K, Bruining N, Dorange C, Miquel-Hebert K, Veldhof S, Webster M, Thuesen L, Dudek D. A bioabsorbable everolimus-eluting coronary stent system (ABSORB): 2-year outcomes and results from multiple imaging methods. Lancet. 2009;373:897-910.

3. Tanimoto S, Bruining N, van Domburg RT, Rotger D, Radeva P, Ligthart JM, Serruys PW. Late stent recoil of the bioabsorbable everolimus-eluting coronary stent and its relationship with plaque morphology. J Am Coll Cardiol. 2008;52:1616-20.

4. Cutlip DE, Windecker S, Mehran R, Boam A, Cohen DJ, van Es GA, Steg PG, Morel MA, Mauri L, Vranckx P, McFadden E, Lansky A, Hamon M, Krucoff MW, Serruys PW; Academic Research Consortium. Clinical end points in coronary stent trials: a case for standardized definitions. Circulation. 2007;115:2344-51.

5. Ludmer PL, Selwyn AP, Shook TL, Wayne RR, Mudge GH, Alexander RW, Ganz P. Paradoxical vasoconstriction induced by acetylcholine in atherosclerotic coronary arteries. $N$ Engl $\mathrm{J} \mathrm{Med.}$ 1986;315:1046-51.

6. Tearney GJ, Regar E, Akasaka T, Adriaenssens T, Barlis P, Bezerra HG, Bouma B, Bruining N, Cho JM, Chowdhary S, Costa MA, de Silva R, Dijkstra J, Di Mario C, Dudek D, Falk E, Feldman MD, Fitzgerald P, Garcia-Garcia HM, Gonzalo N, Granada JF, Guagliumi G, Holm NR, Honda Y, Ikeno F, Kawasaki M, Kochman J, Koltowski L, Kubo T, Kume T, Kyono H, Lam CC, Lamouche G, Lee DP, Leon MB, Maehara A, Manfrini O, Mintz GS, Mizuno K, Morel MA, Nadkarni S, Okura H, Otake H, Pietrasik A, Prati F, Räber L, Radu MD, Rieber J, Riga M, Rollins A, Rosenberg M, Sirbu V, Serruys PW, Shimada K, Shinke T, Shite J, Siegel E, Sonoda S, Suter M, Takarada S, Tanaka A, Terashima M, Thim T, Uemura S, Ughi GJ, van Beusekom HM, van der Steen AF, van Es GA, van Soest G, Virmani R, Waxman S, Weissman NJ, Weisz G; International Working Group for Intravascular Optical Coherence Tomography (IWG-IVOCT). Consensus standards for acquisition, measurement, and reporting of intravascular optical coherence tomography studies: a report from the International Working Group for Intravascular Optical Coherence Tomography Standardization and Validation. J Am Coll Cardiol. 2012;59:105872. Erratum in J Am Coll Cardiol. 2012;59:1662.
7. Virmani R, Burke AP, Kolodgie FD, Farb A. Vulnerable plaque: the pathology of unstable coronary lesions. J Interv Cardiol. 2002:15:439-46.

8. Nishio S, Kosuga K, Igaki K, Okada M, Kyo E, Tsuji T, Takeuchi E, Inuzuka Y, Takeda S, Hata S, Takeuchi Y, Kawada Y, Harita T, Seki J, Akamatsu S, Hasegawa S, Bruining N, Brugaletta S, de Winter S, Muramatsu T, Onuma Y, Serruys PW, Ikeguchi S. Long-term (>10 years) clinical outcomes of first-in-human biodegradable poly-1-lactic acid coronary stents: Igaki-Tamai stents. Circulation. 2012;125:2343-53.

9. Onuma Y, Serruys PW, Perkins LE, Okamura T, Gonzalo N, Garcia-Garcia HM, Regar E, Kamberi M, Powers JC, Rapoza R, van Beusekom H, van der Giessen W, Virmani R. Intracoronary optical cohorence tomography and histology at 1 month and 2, 3, and 4 years after implantation of everolimus-eluting bioresorbable vascular scaffolds in a porcine coronary artery model: an attempt to decipher the human optical coherence tomography images in the ABSORB trial. Circulation. 2010;122:2288-300.

10. Nicholls SJ, Ballantyne CM, Barter PJ, Chapman MJ, Erbel RM, Libby P, Raichlen JS, Uno K, Borgman M, Wolski K, Nissen SE. Effect of two intensive statin regimens on progression of coronary disease. NEngl J Med. 2011;365:2078-87.

11. Nakazawa G, Finn AV, Vorpahl M, Ladich ER, Kolodgie FD, Virmani R. Coronary responses and differential mechanisms of late stent thrombosis attributed to first-generation sirolimus- and paclitaxel-eluting stents. J Am Coll Cardiol. 2011;57:390-8.

12. Karanasos A, Ligthart JM, Regar E. In-stent neoatherosclerosis: a cause of late stent thrombosis in a patient with "full metal jacket" 15 years after implantation: insights from optical coherence tomography. JACC Cardiovasc Interv. 2012;5:799-800.

13. Karanasos A, Simsek C, Serruys P, Ligthart J, Witberg K, van Geuns RJ, Sianos G, Zijlstra F, Regar E. Five-year optical coherence tomography follow-up of an everolimus-eluting bioresorbable vascular scaffold: changing the paradigm of coronary stenting. Circulation. 2012;126:e89-91.

14. Stone GW, Maehara A, Lansky AJ, de Bruyne B, Cristea E, Mintz GS, Mehran R, McPherson J, Farhat N, Marso SP, Parise H, Templin B, White R, Zhang Z, Serruys PW; PROSPECT Investigators. A prospective natural-history study of coronary atherosclerosis. N Engl J Med. 2011;364:226-35. 